\title{
ASSESSMENT OF THE INFLUENCE OF GENERAL ORIENTATION SERVICE ON STUDENTS ADJUSTMENT TO CAMPUS LIFE AT THE CHRIST APOSTOLIC UNIVERSITY COLLEGE AND THE UNIVERSITY OF CAPE COAST IN GHANA
}

\author{
Dr. FELIX SENYAMETOR \\ Faculty of Educational Foundations, Department of Education and Psychology, \\ University of Cape Coast, Ghana \\ $+233242210991$ \\ MICHAEL ASARE \\ School of Education, Christ Apostolic University College, Kumasi, Ghana \\ Tel: +233243133765 \\ MARTIN AKO \\ School of Education, Christ Apostolic University College, Kumasi, Ghana \\ Tel: +233545188270 \\ SETH OSEI KWAME \\ School of Education, Christ Apostolic University College, Kumasi, Ghana \\ Tel: +233248308974 \\ https://doi.org/10.37602/IJSSMR.2021.4210
}

\begin{abstract}
The purpose of this study was to assess the influence of general orientation services conducted by the Christ Apostolic University College (CAUC) and the University of Cape Coast (UCC) on students' adjustment to campus life. The descriptive design was adopted for the study. The target population was all 6,891 second year undergraduate students who were admitted in the 2019/2020 academic year to pursue various programmes, made up of 4,305 males and 2,386 females. The accessible population was 1,505 education students out of which a sample of 150 made up of 95 males and 55 females were randomly sampled for the study. A self-developed closed-ended questionnaire with a reliability coefficient of 0.8 was used to collect data. Descriptive statistical tools such as mean and standard deviation, Pearson product-moment correlation and t-test were used to analyze the data. The results of the study revealed that there was a negative correlation $(\mathrm{r}=-.108, \mathrm{n}=150, \mathrm{p}<.190)$ between the orientation service and students' adjustment to campus life, and there was no statistically significant difference between participants $(\mathrm{M}=28.81, \mathrm{SD}=3.902)$ and non-participants $(\mathrm{M}$ $=27.90, \mathrm{SD}=3.169), \mathrm{t}(150)=1.454, \mathrm{p}=0.150)$ of the orientation activities. Based on the findings of the study, it was recommended that educational institutions should review their orientation programmes to suit the needs of fresh students to enable them to adjust well to academic and campus life.
\end{abstract}




\section{International Journal of Social Sciences and Management Review}

Volume: 04, Issue: 02 "March - April 2021"

ISSN 2582-0176

Keywords: Orientation, Adjustment, Campus Life

\subsection{INTRODUCTION}

Adjusting to a new environment is a transitional challenge for all manner of persons. People who are able to adjust do so with some sort of guidance from persons who know the nittygritty of the place. In educational settings like the university, students have to show a maturity that will enable them to withstand the climate of the new environment. The adjustment refers to the adoption of the organism to the demands of the environment (Senel \& Maraj, 2007). Human beings adapt to their environment through the application of intelligent changes in their lives in order to meet the demands of their environments (Mahmoudi, 2011). Research has shown that students face many challenges in adjusting to new environments, which may have an impact on their academic success and psychological well- being as they interact with their academic and social communities in these new settings (Barratt \& Huba, 1994; Charles \& Stewart, 1991; Pedersen, 1991).

Some empirical reports indicated that most students experience a number of challenges related to accommodations, communication, transportation, social interaction, discrimination, and academic life, which must be tackled to ensure smooth adjustment (Senel \& Maraj, 2007). Their goal is succeeding academically, socially and the institution's interest in retaining and sustaining these students requires that the school or university authorities act to bring about the changes necessary to accomplish these goals. However, the institutions have a very significant role in finding and the resources needed to help students have a successful adjustment experience. While the universities have little control over the district, regional and national issues that may affect student's life on campus, the institutions can provide help for students to cope with and adjust to peculiar issues on campus. Administrators, student service offices, and the faculties within the higher education system can help students successfully adjust to the school environment using orientation service.

Orientation service involves activities embarked upon by the school (counsellor) to help students adjust to the school environment and school experiences (Taylor \& Buku, 2009). In the context of admitting students to the new educational environment, Ogbiji, Eyo and Oko (2011) explained orientation as a programme of activities mounted by the school for new entrants to introduce them to their new environment with regard to the facilities available, academic and non-academic programmes, rules and regulations as well as their superiors and peers. They stated that an orientation programme for new students is supposed to be conducted soon after the admission has been concluded. It is a programme where newly admitted students are formally introduced into the various programmes of the school. These include the curricular and co-curricular programmes. At the secondary school level, it requires informing the students of all the subjects they are expected to offer at their own level. It also requires introducing the various non-academic programmes such as clubs, societies and fellowships that exist within the school. Since university education is a transitional period for students, they are to be helped to go through the transition from the Senior High School level to the tertiary level and adjust to the new environment (Taylor \& Buku, 2006). 


\section{International Journal of Social Sciences and Management Review}

Volume: 04, Issue: 02 "March - April 2021"

ISSN 2582-0176

Orientation service is of importance to students because it helps them to adjust to school socially, psychologically, morally and academically (Ebbin \& Blankenship, 1988; Hovey, 2000). Ogbiji et al (2011) on the other hand, are of the view that orientation programme provides an opportunity for new students to be introduced to facilities available for their use in the school. The facilities may include classrooms or lecture rooms, laboratories, studios and a library. Others are halls of residence, hostels, water supply, toilet facilities and health facilities available. It is during this period that the new entrants are introduced to things they are expected to do and not to do and be provided with the rules and regulation of the school as well as the code of conduct in a form of student's handbooks. It is also an opportunity to interact with the superior officers of the school like the chancellor, vice-chancellor, registrar, deans, heads of departments, librarians, counsellors, and the student leadership. It is expected that intensive and broad-based orientation service will provide a firm foundation for the student to thrive in their academic pursuit and to adjust well to the school environment. With these benefits, this study intends to look at whether orientation service influences students' adjustment to campus life at the Christ Apostolic University College in Kumasi and University of Cape Coast, Ghana.

\subsection{Person-Environment Correspondence Theory (Theory of Work Adjustment)}

This theory according to Dawis and Lofquist (as cited in Winter, 2009) says that "the more closely a person's abilities (skills, knowledge, experience, attitude, behaviours) correspond with the requirements of the role or the organisation, the more likely it is that they will perform the job well and be perceived as satisfactory by the employer. Similarly, the more closely the reinforcers (rewards) of the role or organisation correspond to the values that a person seeks to satisfy through their work, the more likely it is that the person will perceive the job as satisfying"(p.1).

The theory outlined six values people try to satisfy in order to adjust well, learn and succeed in their work and new environment. They include achievement, comfort, status, altruism, safety and autonomy: Fresh students in the light of these expect to be ushered into a safe and stress-free university environment that encourages individual academic accomplishment, independent harmonious relationship with peers and school authorities (Winter, 2009). Meeting these expectations of the fresh students create a pleasant correspondence between the individual needs of the students and their new academic and social environment, a situation prerequisite for adjustment and progress (Dawis \& Lofquist, 1964).

This implies for fresh students of the UCC and CAUC to adjust to campus life are required to meet the needs of their institutions by obeying the rules and regulation of the institutions and performing their academic duties expected of them. Regents of the University of Minnesota (2021) supporting the relevance of the dictates of the Person-Environment Correspondence Theory posited that the environment and the individual students must continue to meet each other's requirements and expectations for the interaction to be maintained. The extent to which the requirements of both are met determines the level of adjustment, otherwise, there would not be an adjustment. Individuals in the environment would persist in wasting their energies complaining about the ills of the environment at expense of work and productivity. In order to forestall this lack of correspondence due to lack of satisfaction on the part of 


\section{International Journal of Social Sciences and Management Review}

Volume: 04, Issue: 02 "March - April 2021"

ISSN 2582-0176

individuals, the theory further maintained that new entrants' skills of manipulating the environment should be developed so that they overcome the ills of their environment through proper orientation service (Dawis \& Lofquist, 1964). Orientation service according to the theory would serve as reinforcement for adjustment. This is because the adjustment is mediated by orientation services(Taylor \& Buku, 2006).

Dawis and Lofquist (1964) in an empirical study at the University of Minnesota established that satisfaction was shown to be a function of the correspondence between need and reinforcement. This implies that new entrants of any environment should be satisfied in the form of meeting their needs and expectations. This is because, research has shown that ignorance of new entrants about their roles and expectations is a significant contributory factor to the lack of correspondence between new entrants and their institutions and environment (Ogbiji, Eyo \& Oko, 2011).

\subsection{The Concept of Orientation Service}

Orientation service involves activities embarked upon by educational institutions to help students adjust to the school environment and academic experiences (Taylor \& Buku, 2006). It is seen as one of the guidance services rendered for the ultimate benefit of students at all levels of the educational system. In an attempt to define orientation, Akinade (2005) stated that it is a guidance service provided to an individual or a group of individuals who are just entering a new environment. The individual may be a student who has just started school (in the primary, secondary or tertiary institutions). It is being stressed that orientation services will help the individuals adjust faster and better to their new environments. (Olusakin, 2011) for instance, found that orientation services make students feel emotionally, mentally and physically secured, as they are assisted to adapt to social and psychological conditions of their environments.

The orientation service is provided to the students who are new entrants and those who go to a new class or prepared to pursue new programmes in the school. It is normally meant for students to get familiar with courses, rules, regulations and facilities that are put at their disposal by the school authorities. The institutions also keep a record of the students about their bio-data, socio-economic background, capacities and abilities, interest for courses and so on (Akinade, 2005).

According to Taylor and Buku (2006), orientation service is of uttermost importance to the students because, it helps them to become more adjusted and established in the school; socially, psychologically, morally and academically. To achieve this, they found that, orientation services are meant to;

A. welcome new students and introduce them to their rights and privileges in the school community as well as their responsibilities to the school.

B. acquaints the new students or 'freshers' with information about school routine, the school traditions, rules and regulations, facilities and personnel.

C. help new students to have a smooth transition from one level of education to another, from one environment to another, and from individual life to school community life. 


\section{International Journal of Social Sciences and Management Review}

Volume: 04, Issue: 02 "March - April 2021"

ISSN 2582-0176

D. make students identify that they are required to meet the academic demands of the school as well as moral values and ethical standards.

Orientation activities are group approaches through which students are given assistance in making plans and adjustment to school. The purpose of orientation according to Oladele (2000) is to help students feel emotionally secure and better adjusted in a new environment, especially during critical transition period say from one level of education to the other or from one school to another. Olusakin (2011) on the other saw orientation as a service with the sole purpose of integrating new school entrants into their new environment while easing the stress associated with the transitions. Adjustment to a new environment for many fresh students does not come easily, therefore, it is often challenging and painful if not properly handled (Yaqub, 2005).

Margaret and Agi (2006) opined that there are several entry shocks for fresh students as they arrive on campus. They identified the following as the reasons for the shock:

a. The large size of the new institution compared to their previous schools.

b. The degree of freedom in the new institution.

c. The sheer variety of human characters drawn from a universal pool who have always lived in a mono-cultural setting.

d. The academic demands of the new institution become overwhelming and stiff to many.

Margaret and Agi (2016) agreeing with Yaqub (2005) stated that the challenges of economic survival, social integration, time budgeting, a new set of study habit, religious life that is punctuated with enormous temptations to drift from God or Allah due to prevalence of social vices such as cultism, militant behaviour, examination malpractice, deliberate disobedience and a voluntary tendency to take risks and die are also manifest in new students. Orientation is needed to ease off these challenges. Yaqub (2005) went further to say that it is the wish of parents, administrators, counsellors and all well-meaning individuals that young people who enter tertiary institutions of learning should realize their goals and lead effective lives thereafter. Students orientation is intended to inform, educate and direct fresh students toward the realisation of their goals. Orientation programme is aimed at delivering the unsuspected students from the dangers awaiting them on campus. Transition from secondary school to tertiary institutions of learning is a major life change for many youths, especially new students entering the Christ Apostolic University College and the University of Cape Coast. Orientation is intended to make these changes palatable in the face of setbacks. In the same vein many researchers believe that entering a tertiary institution may be a source of strain and an acute challenge. This is due to the fact that tertiary institutions are new environments that trigger different reactions among fresh students (Mudhovozi, 2012). In line with this view Habibah, Noordin, and Mahyuddin (2010) found that fresh undergraduate students experience mixed feelings of excitement and apprehension because the increased personal freedom experienced can be wonderful and frightening on one hand as parental control ceases, on the other hand. The students have to reconstruct their personal relations in a new environment and this often causes mental and physical distress. Tao, Dong, Pralt, Hunsberger and Paucer (2000) in a study, revealed that maladjustment with tertiary institution's life often forces 


\section{International Journal of Social Sciences and Management Review}

Volume: 04, Issue: 02 "March - April 2021"

ISSN 2582-0176

some students to leave the institution prematurely. Margaret and Agi (2016) in a related study found that students who withdraw in their first year often do so for personal reasons such as lack of adjustment to their new environment.

The fact is that the involvement of parents and teachers in the academic and social life of students in secondary school is higher than that of the tertiary institution. Students get anxious as they adjust to the academic, social and personal lifestyle the tertiary institution presents. It becomes necessary to introduce orientations service to help them adjust to the several challenges confronting them. Orientation in institutions of higher learning is indispensable because students deal with the transitional problems differently, some deal with adjustment problems constructively others feel overwhelmed and fail to cope with life. Orientation is therefore needed for effective school adjustment and excellent academic performance. A maladjusted student cannot cope with academic life properly. It is only the well-adjusted student that can cope adequately in academic, social and other spheres of life on campus.

\subsection{Topical issues discussed during Orientation Service}

Most educational institutions prepare detailed programmes specifying the activities to be carried out during orientation service. Sometimes, such detailed programmes spell out some topical issues to be discussed during the orientation. Owusu, Tawiah, Sena-Kpeglo and Onyame (2014), commenting on the content of students' orientation at the University of Cape Coast, revealed that a wide range of issues are often addressed during orientation services. These included communication skills, energy conservation in the University, health services, academic programmes, policies and regulations. They also emphasized that topics such as succeeding in the world of learning, regulations for Junior Members (students), sports, disability services, campus security services, dating on campus were often shared with the students during orientation. Again, topics that touched on the structure of the channel of communication, the University policy on sexual harassment among other issues are also discussed.

\subsection{Impact of Orientation Service on Student's Adjustment}

According to Margaret and Agi (2016), orientation can be the defining moment in the transition to higher institutions for the student; a time in which basic habits are formed that influence students' academic success and personal growth and marks the beginning of a new educational experience. Through an orientation, service student learns about the joys, challenges and expectations of the academic way of life. It helps the students to have a smooth transition from one level of education to another, from one environment to another, and from individual life to school community. Also, orientation acquaints the new students with information about the school, the school traditions, rules and regulations, facilities and personnel.

Orientation programmes invigorates and empower student who are often less prepared, from low-income homes and predominantly first-generation students. The programmes equip such students with the knowledge, skills, and abilities to access an array of resources that can help 


\section{International Journal of Social Sciences and Management Review}

Volume: 04, Issue: 02 "March - April 2021"

ISSN 2582-0176

them to have a more successful collegiate and academic experience by 65 percent (Cohen \& Brawer, 2007). This enables students to become self-sufficient and better understand the processes involved with becoming university student and actively engage more effectively in the university campus activities (Mahmoudi, 2011).

\subsection{Gender Difference in Adjustment to College life among Students}

The adjustment refers to the behavioural process of balancing conflicting needs or needs to be challenged by obstacles in the environment (Chowhan, Sakshi, Ravees, 2019). The word 'Adjustment' is, to fit, make suitable, acclimatise, and arrange or modify. Chowhan et al (2019) see adjustment as a multidimensional and continuous process by which a person varies his behaviour to produce a more harmonious relationship between himself and his environment. It is the process that takes one to lead a happy and contented life. It helps a person to maintain balance among various needs that one encounters at a given point in time in life.

According to Chowhan, et al. (2019), both males and females were adjusted differently on the educational adjustment scale. Though none of the differences was statistically significant, females were better adjusted on home adjustment, social adjustment and emotional adjustment subsets of the adjustment scale, as well as equally adjusted on an educational subset of the scale than their male counterparts. This finding has been corroborated by earlier studies (Margaret \& Agi, 2016). Roy, Ekka and Ara (2011) observed that female students were better adjusted in all areas of school adjustment than male students.

Jain and Jandu (1998), Muni and Pavigrahi (1997) and Singh (1995) also found that girls were better adjusted than boys. This resilience in females is attributed to better coping strategies adopted by females to get adjusted to a hostile environment. Taylor (2000) also reported that females were more likely to deal with stress by "tending and befriending"; that is, nurturing those around them and reaching out to others. Tending involves nurturing activities designed to protect the self and offspring that promote safety and reduce distress; befriending is the creation and maintenance of social networks that may aid in this process (Chowhan, et al, 2019). Women are more likely to take a proactive approach, whereas men are more likely to take an avoidant approach. Men more frequently use distraction, alcohol consumption, and denial to cope with their stress symptoms.

Chowhan, et al. (2019) is of the view that a part of the resilience of females is also biologically determined. On exposure to stress, females are better at tackling the situation biologically as they can counter the strain produced by cortisol and epinephrine by the release of oxytocin. While men also secrete the hormone oxytocin when they're stressed, it's in much smaller amounts, leaving them on the short end of the stick when it comes to stress and hormones. At the end of the day, women come quite a long way from the hysterical labels they are often subjected to simply for experiencing normal emotions and mental health conditions.

\subsection{Statement of the Problem}




\section{International Journal of Social Sciences and Management Review}

Volume: 04, Issue: 02 "March - April 2021"

ISSN 2582-0176

During admission into tertiary institutions in Ghana including that of the Christ Apostolic University College and the University of Cape Coast, students go through a lot of challenges. Upon arrival on campus, their major tasks include finding a place to live, registering for courses and classes, as well as identifying and locating unique places on campus. During this transition, sometimes communication and language barriers, in particular, can negatively impact students' well-being and their ability to adjust (Barratt \& Huba, 1994; Hayes \& Lin, 1994; Stoynoff, 1997). Students with higher levels of self-confidence and self-efficacy experience reduced levels of stress and increased levels of adjustment (Hechanova-Alampay, Beehr, Christiansen \& Van Horn, 2002).

At the Christ Apostolic University College and the University of Cape Coast, curriculum and teaching procedures are another adjustment concern for students. These concerns include study techniques, test-taking, classroom instruction, and oral communication such as class discussion. Also, students face the challenge of making new friends, coping with the loss of social support, and developing a new social support system. Loss and lack of social support, in particular, have been found to lead to lower academic achievement and negative psychological experiences such as tension, confusion, and depression (Boyer \& Sedlacek, 1988; Hayes \& Lin, 1994; Hovey, 2000; Pedersen, 1991). Upon arrival to the university campus, individual reactions to campus life and culture may vary. While some become very much involved in the university culture, others may feel upset and become distant. A student's home culture, perceived discrimination, being extroverted, communication skills in English, and positive approach to forming relationships with new and old students are noted as variables accounting for this attitude. Other Psychological experiences students have to battle with include homesickness, confusion, depressive reactions, and feelings of isolation, alienation, and powerlessness (Day \& Hajj, 1986). These stresses combined with the lack of resources could lead to stress-related illnesses such as depression or anxiety (Ebbin \& Blankenship, 1988; Hovey, 2000). Some new entrants of the Christ Apostolic University College and the University of Cape Coast normally experience these adjustments related issues resulting in dropout of school and low academic performance in some cases (Owusu, Tawiah, Sena-Kpeglo \& Onyame, 2014).

Some previous studies have touched on various interventions in schools, colleges and universities to help deal with students' adjustment challenges (Day \& Hajj, 1986; Hovey, 2000). Other researches dealt with fresher orientation programme implementation challenges and strategies for dealing with these challenges during the first semester of course work (Oladele, 2000 \& Babasaheb, 2019). As to whether orientation services influence student adjustment to campus life at the Christ Apostolic University College and the University of Cape Coast is a gap in research that this study has come to fill.

\subsection{Research Questions}

1. What is the nature of the orientation service carried out at the Christ Apostolic University College and the University of Cape Coast?

2. What topical issues were discussed during the orientation service at the Christ Apostolic University College and the University of Cape Coast? 


\section{International Journal of Social Sciences and Management Review}

Volume: 04, Issue: 02 "March - April 2021"

ISSN 2582-0176

3. What was the relationship between orientation service and students' adjustment to college life at the Christ Apostolic University College and the University of Cape Coast?

\subsection{Research Hypothesis}

1. Ho: There is no statistically significant difference in student adjustment to campus life between students who participated and those who did not participate in orientation service at the Christ Apostolic University College and the University of Cape Coast.

2. Ho: There is no statistically significant difference in adjustment between male and female students at the Christ Apostolic University College and the University of Cape Coast.

\subsection{METHODOLOGY}

\subsection{Research Design}

A descriptive survey design was adopted for the conduct of the study. This design was used for the collection of data on the respondents in order to answer the research questions and test the hypotheses on the phenomenon under study. This design was used in order to observe, describe, and document aspects of the phenomenon (orientation and adjustment) as it naturally occurred and investigated.

\subsection{Population}

The target population was all 6,891 level 200 undergraduate students who were admitted to pursue various programmes, made up of 4,305 males and 2,386 females. The UCC population comprised 4,112 males and 2,298 females (Daily Graphic, 2019) while the CAUC population was made up of 193 males and 88 females. The accessible population was 1,505 education and business students made up of 1,261 UCC students and 244 Christ Apostolic University College Students (CAUC, 2019).

\subsection{Sample and Sampling Technique}

The accessible population was 1,505 made up of 1,261 UCC students and 244 Christ Apostolic University College Students out of which a sample of 150 made up of 95 males and 55 were selected. The sample comprised 126 UCC students and 24 CAUC students. The sample was selected based on Creative Research Systems (2012) and Kumar (2010) criteria for sample selection which per their calculation, 10 per cent of the accessible population is representative enough for descriptive surveys. The sample for the study was 150 made up of 95 males and 55 females. The level 200 students were purposively sampled for the study because they were the ones who had just gone through the orientation and were getting adjusted to campus and academic life. Drop out normally occurs at this point on the part of ill-adjusted students (Owusu, Tawiah, Sena-Kpeglo \& Onyame, 2014). The proportionate sampling procedure was first used to allocate 3.6 per cent for male students and 6.3 per cent for female students with regard to the gender strata. This was followed by the lottery method 


\section{International Journal of Social Sciences and Management Review}

Volume: 04, Issue: 02 "March - April 2021"

ISSN 2582-0176

of simple random sampling technique to select the respondents based on the male-female sampling frames prepared.

\subsection{Data Instrument}

A self-developed closed-ended questionnaire with a reliability coefficient of 0.8 was used to collect data from the respondents. The questionnaire consisted of four sections (A, B, C and D). The first section (A) dealt with items on the background characteristics of respondents. The rest of the sections (B, C and D) touched on responses to issues based on the phenomenon understudy captured in the research questions and hypotheses. These issues include the nature of orientation service that took place in the universities, topical issues discussed during the orientation service and the kind of adjustment made by the students after attending the orientation programmes respectively. The items were measured on a unilinear four-point Likert scale, which ranged from strongly agree (4) through 'agree (3) and disagree (2) to strongly disagree (1).

\subsection{Data Collection Procedures}

Data were collected using the questionnaire from one university to the other by the researchers. The questionnaire was administered at the end of the lecture periods. This lasted for three weeks.

\subsection{Data Analysis}

The data was carefully edited, coded and entered into the computer and analysed using the Predictive Analytics Software (PASW) version 21 software. Descriptive statistics such as frequencies and percentages counts were used to analyse the background data of the respondents. Also, mean and standard deviation were used to analyse research questions 1 and 2. Pearson product-moment correlation was used to analyse research question 3, and hypotheses 1 and 2 were analysed using independent samples test.

\subsection{RESULTS}

\subsection{Results}

Background data collected from respondents covered issues regarding their gender and attendance of orientation programmes. Data regarding the issues were analysed using frequency and percentage counts and are presented in Tables 1 and 2 respectively.

Table 1: Gender of respondents

\begin{tabular}{lcc}
\hline Gender & Frequency & Valid Percent $(\boldsymbol{\%})$ \\
\hline Male & 95 & 63.3 \\
Female & 55 & 36.7 \\
\hline Total & $\mathbf{1 5 0}$ & $\mathbf{1 0 0 . 0}$ \\
\hline
\end{tabular}

Source: Field Data, 2020 


\section{International Journal of Social Sciences and Management Review}

Volume: 04, Issue: 02 "March - April 2021"

ISSN 2582-0176

Table 1 depicts the gender of respondents. It shows that out of the 150 respondents selected for the study, $95(63.3 \%)$ were male whiles 55 (36.7\%) were female.

Table 2: Attendance to Orientation Services

\begin{tabular}{lcc}
\hline Responses & Frequency & Valid Percent (\%) \\
\hline Yes & 111 & 74.0 \\
No & 39 & 26.0 \\
\hline Total & $\mathbf{1 5 0}$ & $\mathbf{1 0 0 . 0}$ \\
\hline
\end{tabular}

Source: Field Data, 2020.

Table 2 shows that out of the 150 respondents 111 (74.0\%) responded 'yes', which showed that they participated in the orientation programme organized by the universities during the 2018/2019 academic year, while 39 (26.0\%) responded 'no', which indicated that they did not take part in the orientation programme.

\subsubsection{Research Question One: What is the Nature of orientation service carried out at the Christ Apostolic University College and University of Cape Coast?}

Research question One sought to find out the nature of orientation services carried out at the Christ Apostolic University College and University of Cape Coast. Issues covered include whether the orientation was done in a conducive atmosphere, the resource helped respondents to understand issues concerning academic and social life on campus, and whether resource persons demonstrated professional competence on subject-matter knowledge. Others include whether or not resource persons demonstrated patience in answering all questions posed by the participants, used lecture approach to present the issue during the orientation and whether respondents were satisfied with the orientation service rendered. Means and standard deviations were used to analyse the question and the results are presented in table 4.

Table 4: Nature of Orientation Service

\begin{tabular}{|c|c|c|}
\hline Items & $\mathbf{M}$ & SD \\
\hline $\begin{array}{l}\text { 1. The orientation was conducted in a conducive atmosphere } \\
\text { free from distractions. }\end{array}$ & 3.12 & .40 \\
\hline $\begin{array}{l}\text { 2. The resource persons helped me to understand issues } \\
\text { concerning my academic and social life on campus. }\end{array}$ & 3.16 & .50 \\
\hline $\begin{array}{l}\text { 3. The resource persons demonstrated professional } \\
\text { competence on subject-matter knowledge. }\end{array}$ & 2.74 & .85 \\
\hline $\begin{array}{l}\text { 4. The resource persons had patience to answer all questions } \\
\text { posed by the participants during the orientation }\end{array}$ & 3.11 & .65 \\
\hline $\begin{array}{l}\text { 5. The resource persons used lecture approach to present the } \\
\text { issue during the orientation. }\end{array}$ & 2.67 & .86 \\
\hline $\begin{array}{l}\text { 6. I am satisfied with the orientation service rendered and the } \\
\text { assistance given by the resource persons during the entire } \\
\text { sessions. }\end{array}$ & 2.86 & .89 \\
\hline
\end{tabular}

(MS=2.78, SD=0.69) 


\section{International Journal of Social Sciences and Management Review}

Volume: 04, Issue: 02 "March - April 2021"

ISSN 2582-0176

Table 4 captures the nature of orientation service carried out by the universities for the respondents. The mean of the items ranged from 2.67 to 3.16 whiles the Standard Deviation ranged from 0.40 to 0.89 . The item which asked about the approach in which the resource persons presented the issues to the participants during the orientation had the lowest mean $(\mathrm{M}=2.67, \mathrm{SD}=.86)$. This means that the participants disagreed with the lecture method used by the resource persons. The, highest mean $(M=3.16, .50)$ shows that the resource persons helped the students to understand issues concerning their academic and social life on campus. This indicates that the majority of the students agreed that the resource persons assisted the students to gain an understanding of issues concerning their academic life and social life on campus.

\subsubsection{Research Question Two: What topical issues were discussed during the orientation service at the University of Cape Coast and Christ Apostolic University College?}

Research question Two examined issues pertaining topical issues covered during orientation at the universities. The issues examined ranged from, time management, safety and security, available resources on campus, relationship matters to communication and religious matters. Means and standard deviations were used to analyse the question and the results are presented in table 5 .

Table 5: Topical Discussed during the Orientation Service

\begin{tabular}{|c|c|c|}
\hline Topics & $\mathbf{M}$ & SD \\
\hline $\begin{array}{l}\text { 1. Time Management was discussed during the orientation } \\
\text { service. }\end{array}$ & 2.65 & .84 \\
\hline $\begin{array}{l}\text { 2. Safety and security issues were discussed during the } \\
\text { orientation. }\end{array}$ & 2.61 & .89 \\
\hline $\begin{array}{l}\text { 3. The orientation brought to light the resources available on } \\
\text { campus to be used. }\end{array}$ & 2.74 & .85 \\
\hline $\begin{array}{l}\text { 4. Building and sustaining relationship were most of my } \\
\text { favourite issues discussed during the orientation. }\end{array}$ & 2.77 & .85 \\
\hline $\begin{array}{l}\text { 5. Channel of Communication in the University College was } \\
\text { taught during the orientation. }\end{array}$ & 2.65 & .91 \\
\hline $\begin{array}{l}\text { 6. Joining of clubs, societies and religious groups on campus } \\
\text { were introduced during the orientation. }\end{array}$ & 2.59 & .93 \\
\hline
\end{tabular}

$(\mathrm{MS}=2.67, \mathrm{SD}=.87)$

Table 5 presents the topics discussed during the orientation service. The Mean of the items ranged from 2.59 to 2.77 whiles the Standard Deviation ranged from 0.84 to 0.93 . The table revealed that joining of clubs, societies and religious groups on campus had the lowest mean $(\mathrm{M}=2.59, \mathrm{SD}=.93)$. The means for Time Management $(\mathrm{M}=2.65, \mathrm{SD}=.84)$, Safety and security issues $(\mathrm{M}=2.61, \mathrm{SD}=.89)$, Channel of Communication $(\mathrm{M}=2.65, \mathrm{SD}=.91)$ are also low as compare to the overall mean. This means that the participants disagreed that the latter was discussed during the orientation. Also, the topic with the highest mean was building and 


\section{International Journal of Social Sciences and Management Review}

Volume: 04, Issue: 02 "March - April 2021"

ISSN 2582-0176

sustaining relationship $(\mathrm{M}=2.77, .85)$. This indicates that majority of students agreed that relationship building and its sustenance was discussed during the orientation.

3.1.3 Research Question Three: What is the relationship between Orientation Service and Students' Adjustment at the Christ Apostolic University College and University of Cape Coast?

Research question Three sought to find out whether there was a significant relationship between orientation service and students' adjustment at the Christ Apostolic University College and University of Cape Coast. Pearson product-moment correlation coefficient was used to analyse the question and the results are presented in Table 6.

Table 6: Correlation between orientation service and students' adjustment to college life

\begin{tabular}{llcc}
\hline & & $\begin{array}{c}\text { Attendance to } \\
\text { Orientation }\end{array}$ & $\begin{array}{c}\text { Adjustment to } \\
\text { College life }\end{array}$ \\
\hline Attendance to & Pearson Correlation & 1 & -.108 \\
Orientation & Sig. (2-tailed) & 150 & .190 \\
\multirow{2}{*}{ Adjustment to college } & $\mathrm{N}$ & -.108 & 150 \\
Life & Pearson Correlation & .190 & 1 \\
& Sig. (2-tailed) & 150 & 150 \\
\hline
\end{tabular}

Source: Field Data, 2020

Table 6 shows the correlation between orientation service and students' adjustment to campus life. Preliminary analyses were performed to ensure no violation of the assumptions of normality, linearity and homoscedasticity. There was a significant negative correlation between the two variables $(\mathrm{r}=-.108, \mathrm{n}=150, \mathrm{p}<.190)$.

3.1.4 Hypothesis One: There is no statistically significant difference in students' adjustment to campus life between students who participated and those who did not participate in orientation services.

Hypothesis One sought to find out whether there was a significant difference in students' adjustment to campus life between students who participated and those who did not participate in orientation services. Independent samples t-test was conducted to compare the Adjustment to College life scores for Participant and Non-participants of general orientation services. The results are presented in Table 7.

Table 7a: Group Statistics for mean difference in adjustment to college life for participants and non-participants in general orientation.

\begin{tabular}{lccccc}
\hline & Attendance to Orientation & N & Mean & $\begin{array}{c}\text { Std. } \\
\text { Deviation }\end{array}$ & $\begin{array}{c}\text { Std. Error } \\
\text { Mean }\end{array}$ \\
\hline Adjustment to College & Yes & 111 & 28.81 & 3.902 & .370 \\
Life & No & 39 & 27.90 & 3.169 & .507 \\
\hline
\end{tabular}




\section{International Journal of Social Sciences and Management Review}

Volume: 04, Issue: 02 "March - April 2021"

ISSN 2582-0176

\section{Source: Field data, 2020; $N=150$}

Table 7 shows the mean and standard deviation for each of the group (Participants and Nonparticipants of General orientation service) in terms of adjustment. The mean and standard deviation of participants (Yes) of the general orientation are 28.81 and 3.902 respectively. On the other hand, the mean and standard deviation for Non-participants (No) are 27.90 and 3.169 respectively.

Table 7b: Independent samples test

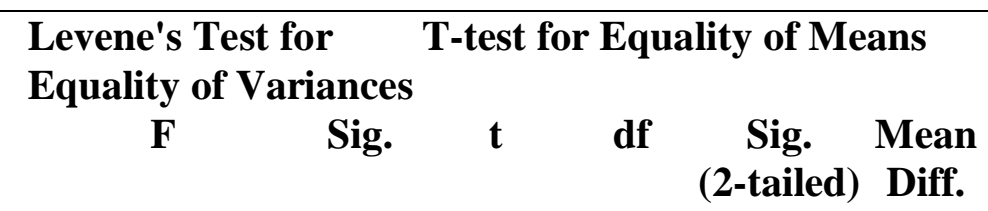

Equal variances assumed

5.784

$.017 \quad 1.316 \quad 148$

.190

.913

Adjustment to

College Life

Equal variances not assumed

\section{Source: Field data, 2020; $N=150$}

Table $7 \mathrm{~b}$ shows the independent sample test. The preliminary section of the Independent Samples Test output gives the results of Levene's test for equality of variances. This evaluates whether the variance (variation) of scores for the two groups (Participants and Nonparticipants of general orientation) are the same. According to the table, since the significance level of Levene's test is less than .05 (.017), means that the assumption of equality variances has been violated; and that the variances for the two groups are not the same. Thus, equal variance not assumed was used in assessing differences between the groups. Since its corresponding value in the Sig. (2-tailed) the column is greater than 05 (.150), there is no significant difference in the mean scores on the dependent variable (Adjustment to College Life) for each of the two groups.

The independent sample t-test conducted to compare the Adjustment to College life scores for Participant and Non-participants of general orientation service revealed that, there was no statistically significant difference in scores for participants $(\mathrm{M}=28.81, \mathrm{SD}=3.902)$ and nonparticipants $(\mathrm{M}=27.90, \mathrm{SD}=3.169), \mathrm{t}(150)=1.454, \mathrm{p}=0.150)$. In effect, the null hypothesis which states that there is no statistically significant difference in adjustment to campus life between participants and non-participants' students is accepted.

3.1.6 Hypothesis Two: There is no statistically significant difference in Adjustment to Campus Life between Male and Female Students. 


\section{International Journal of Social Sciences and Management Review}

Volume: 04, Issue: 02 "March - April 2021"

ISSN 2582-0176

Hypothesis Two sought to find out whether there was a statistically significant difference in adjustment to campus life between male and female students. The independent samples t-test was used to analyse the data and results presented in Table 8.

Table 8a: Group Statistics for mean Difference in Gender on Adjustment to Campus Life

\begin{tabular}{lccccc}
\hline & Gender & N & Mean & $\begin{array}{c}\text { Std. } \\
\text { Deviation }\end{array}$ & $\begin{array}{c}\text { Std. Error } \\
\text { Mean }\end{array}$ \\
\hline $\begin{array}{l}\text { Adjustment to College } \\
\text { Life }\end{array}$ & Male & 95 & 28.98 & 3.73 & .383 \\
Female & 55 & 27.87 & 3.68 & .496 \\
\hline
\end{tabular}

Source: Field Data, 2020, $\mathrm{N}=150$

Table 8 shows the mean and standard deviation for each of the groups (Male and female) in terms of adjustment $(\mathrm{M}=28.98, \mathrm{SD}=3.7 \& \mathrm{M}=3.68, \mathrm{SD}=.496)$ respectively.

Table 8b: Group Statistics for mean Difference in Gender on Adjustment to Campus Life.

\begin{tabular}{|c|c|c|c|c|c|c|c|c|}
\hline & & \multicolumn{2}{|c|}{$\begin{array}{l}\text { Levene's Test } \\
\text { for Equality } \\
\text { of Variances }\end{array}$} & \multicolumn{5}{|c|}{ T-test for Equality of Means } \\
\hline & & $\mathbf{F}$ & Sig. & $\mathbf{t}$ & df & $\begin{array}{c}\text { Sig. } \\
\text { (2-tailed) }\end{array}$ & $\begin{array}{l}\text { Mean } \\
\text { Diff. }\end{array}$ & $\begin{array}{c}\text { Std. } \\
\text { Error } \\
\text { Diff. }\end{array}$ \\
\hline \multirow{2}{*}{$\begin{array}{l}\text { Adjustment to } \\
\text { College Life }\end{array}$} & $\begin{array}{l}\text { Equal variances } \\
\text { assumed }\end{array}$ & .179 & .673 & 1.759 & 148 & .081 & 1.106 & .629 \\
\hline & $\begin{array}{l}\text { Equal variances } \\
\text { not assumed }\end{array}$ & & & 1.766 & 114.224 & .080 & 1.106 & .626 \\
\hline
\end{tabular}

\section{Source: Field data, 2020, $\mathrm{N}=150$}

Table $8 \mathrm{~b}$ presents the independent sample test. The initial section of the Independent Samples Test output gives the results of Levene's test for equality of variances. This assesses whether the variance (variation) of scores for the two groups (Male and female) are the same. According to the table, since the significance level of Levene's test is greater than .05 (.673), this means that the assumption of equal variances has not been violated; and that the variances for the two groups are the same. Thus, equal variance assumed is used in assessing differences between the groups. There is no significant difference (.081), in the mean scores on the dependent variable (Adjustment to College Life) for each of the two groups.

The independent sample t-test conducted to compare the adjustment to campus life scores for male and female revealed that, there was no statistically significant difference between males $(\mathrm{M}=28.98, \mathrm{SD}=3.730)$ and female $(\mathrm{M}=27.87, \mathrm{SD}=3.677), \mathrm{t}(150)=1.759, \mathrm{p}=0.081$. Therefore, the null hypothesis which states that there is no statistically significant difference in adjustment between male and female students is accepted and the alternate hypothesis which state that there is a statistically significant difference in adjustment between male and female students was rejected. 


\section{International Journal of Social Sciences and Management Review}

Volume: 04, Issue: 02 "March - April 2021"

ISSN 2582-0176

\subsubsection{Key Findings}

Based on the study, the following key findings emerged:

1. Regarding the nature of the orientation service carried out, participants disagreed with the lecture method used by the resource persons during the orientation service.

2. It was also revealed that the participants agreed that building and sustaining relationship, the most favourite subject was discussed during the orientation service. Respondents, however, disagreed that issues regarding joining of clubs, societies, religious groups on campus, time management, safety and security issues as well as channels of communication in the universities were discussed during the orientation.

3. There was a negative correlation between the orientation service and student's adjustment to college life.

4. There was no statistically significant difference in adjustment to college life between participants and non-participants of orientation.

5. There was no statistically significant difference in adjustment to campus life between male and female students.

\subsection{DISCUSSIONS OF RESULTS}

Findings of this study (Table 4) revealed that the participants disagreed (2.67, SD=.86) with some aspect of the nature of orientation service carried out, particularly the use of lecture method of presentation of issues. This finding is in line with that of Kaur (2011) which revealed that the lecture method when solely used, students would not understand and personalise issue and concepts for application in their lives. The findings further pointed out that, in the process of lecturing, students are often passive, thus evaluation and feedback which are important in the development of orientation programmes are lost. The findings $(\mathrm{M}=3.16, \mathrm{SD}=.50)$ on the other hand shows that the resource persons helped the students to understand issues concerning their academic and social life on campus. This indicates that majority of the students agreed that the resource persons assisted the students to gain an understanding of issues concerning their academic life and social life on campus.

The study (Table 5) further indicated that most participants agreed $(\mathrm{M}=2.77, .85)$ that building and sustaining relationship was discussed during the orientation, a subject most liked. This finding corroborates that of Owusu et al (2014) which pointed out that orientation sessions are to provide students with the opportunity to meet one another and develop new relationships, which could emerge new friends who share their experiences thereby serving as an important source of support and information. This finding further supported the theory of Person-Environment Correspondence Theory (as cited in Winter, 2009) which states that fresh students expect to be ushered into a safe and stress-free university environment that encourages individual academic accomplishment, independent harmonious relationship with peers and school authorities. It is, therefore, necessary to factor issues of relationship into every orientation programme for fresh students to enable them to enjoy the company of friends and adjust better to the new school environment. The study, however, indicated that respondents disagreed that the channel of communication $(\mathrm{M}=2.65, \mathrm{SD}=.91)$ as a subject was addressed during the orientation services. This finding contradicts that of Senel and Maraj 


\section{International Journal of Social Sciences and Management Review}

Volume: 04, Issue: 02 "March - April 2021"

ISSN 2582-0176

(2007) which indicates that most students experience a number of challenges related to accommodations, communication, transportation, social interaction, discrimination, and academic life, which must be tackled to ensure smooth adjustment. It is, therefore, expedient for all institutions of higher education to factor issues pertaining to accommodations, channels of communication, transportation, social interaction, discrimination and academic life into their orientation programmes.

The study in Table 6 revealed that there was a significant negative correlation between the orientation service and student's adjustment to campus life $(r=-.108, \mathrm{n}=150, \mathrm{p}<.190)$.

This means there is an inverse relationship between the two variables (orientation and students' adjustment to campus life). That is, as one variable (orientation) increases, the other variable (Student adjustment) decreases. This result, therefore, points to the fact that the orientation services run at the universities did not address the pressing adjustment needs of the newly admitted students during the academic year (2019/2020) understudy. This could be attributed to the fact that issues regarding joining of clubs, societies, religious groups on campus, time management, safety and security issues as well as channels of communication in the universities were not addressed during the orientation, which might be most relevant for students' adjustment. This finding is in line with Regents of the University of Minnesota (2021) supporting the relevance of the dictates of the Person-Environment Correspondence Theory (Dawis and Lofquist, 1964) posited that the environment and the individual students must continue to meet each other's requirements and expectations for the interaction to be maintained. The extent to which the requirements of both are met, determines the level of adjustment, otherwise there would not be an adjustment. Individuals in the environment would persist in wasting their energies complaining about the ills of the environment at expense of work and productivity. The finding, however, contradicts that of Babasaheb, (2019) which pointed to orientation programmes a viable component of campus transition and retention efforts as students recognise their value and importance in their enrolment and adjustment to campus.

Oladele (2000), corroborating the findings of Pickard et al (2020) opined that orientation activities are ways through which students are given support in making plans and adjustment to school. The purpose of orientation according to him is to help students feel emotionally secure and better adjusted in a new environment, especially during the critical transition period; from one level of education to the other or from one school to another. Participants of orientation activities are able to get integrated into their new environment while easing the stress associated with the transitions.

However, the results in Table 7 of this study revealed that there was no statistically significant difference between participants $(\mathrm{M}=28.81, \mathrm{SD}=3.902)$ and non-participants $(\mathrm{M}$ $=27.90, \mathrm{SD}=3.169), \mathrm{t}(150)=1.454, \mathrm{p}=0.150)$ of the orientation activities. This finding calls to question the relevance of the orientation activities and how they are addressing the adjustment needs of newly admitted students to adjust well to campus life. This finding contradicts the purpose of orientation programmes in institutions as found by Olusakin (2011) that, the purpose of orientation service is an adjustment to a new environment. Akinade (2005) in support further stated that orientation will help the individuals to adjust faster and better to their new environments. It will make them feel emotionally, mentally and physically 


\section{International Journal of Social Sciences and Management Review}

secured, adapt to the social and psychological conditions of their environments. It is expected that participants of orientation activities will show much adjustment than the nonparticipants. Taylor \& Buku (2006) also in support opined that orientation service is of grave importance to the students because it helps them to become more adjusted and established in the school; socially, psychology, morally and academically.

The study further revealed in Table 8 that there was no statistically significant difference between males $(M=28.98, S D=3.730)$ and females $(M=27.87, S D=3.677), t(150)=$ $1.759, \mathrm{p}=0.081$ ) in adjustment to campus life. The research hypothesis was, therefore, rejected and the null hypothesis which states that there is no statistically significant difference in adjustment between male and female students is accepted. This result implies that both male and female students are able to adjust well to campus life. This finding contradicts that of Roy, Ekka and Ara (2011) who found a statistically significant difference between males and female newly admitted students, where female students were found to be better adjusted in all areas of campus life than their male counterparts. Jain and Jandu (1998), Muni and Pavigrahi (1997) and Singh (1995) revealed that this resilience and smooth adjustment in females is attributable to better coping strategies adopted by females in hostile environments. Taylor (2000) also reported that females were more likely to deal with stress by "tending and befriending"; that is, nurturing those around them and reaching out to others. Women are more likely to take a proactive approach, whereas men are more likely to take an avoidant approach. Men more frequently use distraction, alcohol consumption, and denial to cope with their stress symptoms (Tatlor, 2000).

Chowhan, Sakshi and Ravees (2019) are also of the view that a part of the resilience of females is also biologically determined. On exposure to stress, females are better at tackling the situation biologically as they can counter the strain produced by cortisol and epinephrine by the release of oxytocin. While men also secrete the hormone oxytocin when they are stressed, it is in much smaller amounts, leaving them on the short end of the stick when it comes to stress and hormones (Chowhan, et al. 2019).

\subsection{CONCLUSION}

This study revealed that participants appear to be dissatisfied with the nature of orientation that took place, particularly the method of presentation, the channel of communication and topical issues discussed during the programme. Nonetheless, the study revealed that the participants established that issues bothering on building and sustaining relationship were discussed during the orientation.

\subsection{RECOMMENDATIONS}

Based on the findings of the study, the following recommendations are made:

1. Educational institutions must adopt the very best medium and approach to present issues during orientation programmes for fresh students.

2. Topical issues should be elaborated and thoroughly discussed during programmes to orient new students to enable them to adjust to their new school environment. 


\section{International Journal of Social Sciences and Management Review}

Volume: 04, Issue: 02 "March - April 2021"

ISSN 2582-0176

3. Issues regarding channels of communication and security in the university community should be given prior attention in orientation services as they form an integral part of students' interaction with various departments, units and resolution of their academicrelated challenges in the university.

4. University managements should research thoroughly into cores issues that enable newly admitted students to adjust and factor them into their orientation services to enable them easily adjust to their new academic environment.

5. Educational institutions should review their current orientation programmes to suit the needs of fresh students to enable them to adjust well to academic and campus life.

\section{REFERENCES}

Akinade, E. A. (2005). Dictionary of guidance and counseling (Counseling Psychology). Lagos: Olu-Akin

Babasaheb, R.R. (2019). A study of adjustment among male and female college going students. The International Journal of Indian Psychology. Retrieved from http://www.ijip.in 18.01.125/20190704DOI: 10.25215/0704.125. 7(4) 1-10

Barratt, M. F., \& Huba, M. E. (1994). Factors related to international undergraduate student adjustment in an American community. College student journal, 2(8) 422-435.

Boyer, S., \& Sedlacek, W. (1988). Noncognitive predictors of academic success for international students: A longitudinal study. Journal of college student development, $29(2) 18-223$.

Chowhan, A., Sakshi, M., \& Ravees, S. (2019). Gender difference in adjustment among the college students of Jammu city. International journal of applied research. 5(8), 17-20

Christ Apostolic University College (2019). Admission unit, christ apostolic university college. Kumasi, Ghana

Cohen, A. M. \& Brawer, F. B. (2007). The American community college (4 $4^{\text {th }}$ ed.). San Francisco: Jossey - Bass.

Creative Research Systems (2012). Sample size calculator. Retrieved from https://www.surveysystem.com/contact.htm

Daily Graphic (2019). UCC matriculates 7,401 students. Retrieved from https://www.graphic.com.gh/news/education/ucc-matriculates-7-401students.html

Day, R., \& Hajj, F. (1986). Delivering counseling services to international students: the experience of the American University of Beirut. Journal of college student personnel, 2(7), 353-357. 


\section{International Journal of Social Sciences and Management Review}

Volume: 04, Issue: 02 "March - April 2021"

ISSN 2582-0176

Pickard, L., Brunton, J., McKenna, J., \& Utley, A. (2020). Aiding Transition to University Through an Outdoor Orientation Program: Accelerated Friendships. Journal of College Orientation, Transition, and Retention, 27(2). Retrieved from https://pubs.lib.umn.edu/index.php/jcotr/article/view/2433

Ebbin, A. J., \& Blankenship, E. S. (1988). Stress-related diagnosis and barriers to health care among foreign students: Results of a survey. Journal of American college health, 3(6), 311- 312.

Habibah, E., Noordin, N., Mahyuddin, R. H. (2010). Achievement motivation and selfefficacy in relation to adjustment among university students. Journal of social sciences 6 (3), 333-339.

Hayes, L. H., \& Lin H. R. (1994). Corning to America: Developing social support systems for international students. Journal of multicultural counselling and development. 2(2), 7-16.

Hechanova-Alampay, R., Beehr, T. A., Christiansen,N.D., and Van Horn, R. K. (2002). Adjustment and strain among domestic and international student sojourners: A longitudinal study. School psychology international, 2(23), 458-475.

Hovey, J. (2000). Psychosocial predictors of depression among central American immigrants. Psychological reports, 8(6), 1237-1240.

Jain, P. \& Jandu, K. (1998). A comparative study of school adjustment of adolescent girls and boys. J. Edu. Res. Extn. 35(2), 14-21.

Kumar, B. N (2010) Understanding the relevance of sample size calculation. Indian Journal of Ophthalmology. Retrieved from https://www.ncbi.nlm.nih.gov/pmc/articles/PMC2993974/doi: 10.4103/03014738.71673. 58(6): 469-470.

Margaret, K. G. \& Agi, C. (2016). Role of Students Orientation as School Adjustment among Students of Tertiary Institution. Journal of technical and science education (JOTASE)

Mahmoudi, A. (2011). Influences gender on adjustment and self-esteem among adolescents.

Retrived from http://ijemr.in/wp

content/uploads/2018/01/Influences_gender_on_adjustment_and_self-

esteem_among_adolescents.pdf

Mudhovozi, P. (2012). Social and Academic Adjustment of First-Year University

Students, Journal of social sciences. Retrieved from DOI: 10.1080/09718923.2012.11893103. 33 (2), 251-259,

Muni, A. K. \& Pavigrahi, B. (1997). Effect of maternal employment on school going 


\section{International Journal of Social Sciences and Management Review}

Volume: 04, Issue: 02 "March - April 2021"

ISSN 2582-0176

children's adjustment problems. Journal comm. Guid. Res. 14(3):209-216.

Ogbiji, J. E; Eyo, M. B \& Oko, P. I. O. (2011). The Extent of implementation of orientation programme among public and private secondary schools in Cross River State of Nigeria. An International multi-disciplinary journal, Ethiopia. 5(19), 215-224

Oladele, J.O. (2000). Guidance and counseling. A functional approach: focus on the 63-3-4 educational system. Yaba: Johns- Lad Publishers Ltd.

Olusakin. (2011). Guidance and counselling yesterday, today and tomorrow. An inaugural lecture delivered at the University of Lagos: On Wednesday 12th October, 2011.

Owusu, G. A., Tawiah, M. A., Sena-Kpeglo, C. \& Onyame, J. T. (2014). Orientation impact on performance of undergraduate students in University of Cape Coast (Ghana). International journal of educational administration and policy. 6(7), 131-140

Pedersen, P. (1991). Counseling international students. The Counseling Psychologist, 1(9), $10-58$.

Regents of the University of Minnesota (2021). Theory of work adjustment. Retrieved from https://vpr.psych.umn.edu/theory-work-adjustment

Roy, B., Ekka, A. \& Ara, A. (2011). Adjustment among university students. Journal for social Development, ISDR. Ranchi.; 2(2). 1467-9507

Senel, P. \& Maraj G. K. (2007). Barriers to adjustment: Needs of international students within a semi-urban campus community. Retrieved from https://www.redorbit.com/news/education/907480/barriers_to_adjustment_needs_of_i nternational_students_within_a_semiurban/index.html/

Singh A. K. (1995). A study of parent-child relationship and adjustment problem among preadolescent. An unpublished Ph.D. thesis, L.N.M.U. Darbhanga.

Stoynoff, S. (1997). Factors associated with international student's academic achievement. Journal of instructional psychology, 24, 56-68.

Tao, S., Dong, O., Pratt, M.W., Hunsberger, B. \& Pancer, S.M. (2000). Social support:

Relations to coping and adjustment during the transition to university in the peoples republic of china. Journal of adolescent research 1(5), 123- 144.

Taylor, S. E., Klein, L. C., Lewis, B. P., Gruenewald, T. L., Gurung, R. A. R. \& Updegraff, J.

A. (2000). Biobehavioural responses to stress in females: Tend-and-befriend, not fight-or-flight. Psychological Review. 107(3), 411-429.

Taylor, A. I. \& Buku, D. K. (2009). Basics in guidance and counselling. (2 ${ }^{\text {nd }}$ Ed.). Winneba: Department of Psychology and Education, University of Education, Winneba 


\section{International Journal of Social Sciences and Management Review}

Volume: 04, Issue: 02 "March - April 2021"

Taylor, A. I. \& Buku, D. K. (2006). Basics in guidance and counselling. Winneba: Department of Psychology and Education, University of Education, Winneba

Weiss, D. J., Dawis, R. V., England, G. W., \& Lofquist, L. H. (1964). Construct validation studies of the Minnesota Importance Questionnaire. Minnesota Studies in Vocationa Rehabilitation, 18, 1-76.

Winter, D. (2009). Theory of work adjustment. Retrieved from https://careersintheory.files.wordpress.com/2009/10/theories_twa.pdf

Yaqub, N.O. (2005). Foreword for counselling students for effective campus life. Abuja: Nigeria. University Press. 